\title{
Influence of phosphorus and sulphur on growth, yield and yield attributes of tomato in calcareous soil
}

P. R. KALPANA, R. SUMA AND M. S. NAGARAJA

Received : 10.11.2014; Revised : 03.05.2015; Accepted : 14.05.2015

MEMBERS OF RESEARCH FORUM:

Corresponding author :

P.R. KALPANA, Department of Soil Science and Agricultural Chemistry, College of Horticulture, University

of Horticultural Sciences, BAGALKOT (KARNATAKA) INDIA

Email: kalpa228@gmail.com

\section{Co-authors :}

R. SUMA AND M.S. NAGARAJA

Department of Soil Science and Agricultural Chemistry, College of Horticulture, University of Horticultural Sciences, BAGALKOT (KARNATAKA) INDIA

\begin{abstract}
Summary
Tomato is an important commercial vegetable crop grown throughout the world, is also known to tolerate the calcareous soil conditions. But, phosphorus availability is a major constrain affecting its yield and productivity. Application of sulphur(S) is known to enhance its availability through bio-chemical reactions and desorption process. To ascertain the quantity of $\mathrm{P}$ and $\mathrm{S}$ required to enhance the productivity of tomato, a field experiment was conducted in calcareous clay loam soil with five levels of $\mathrm{P}_{2} \mathrm{O}_{5}\left(312.5,250,187.5,125\right.$ and $\left.0 \mathrm{~kg} \mathrm{ha}^{-1}\right)$ and four levels of $\mathrm{S}$, applied at the rate of 2.5, 1.5, 0.5 and 0 per cent $(\mathrm{w} / \mathrm{w})$ equivalent to active $\mathrm{CaCO}_{3}$ in soil. Increased rate of $\mathrm{P}$ and $\mathrm{S}$ application enhanced tomato growth recording highest with $\mathrm{P}_{312.5}+$ $\mathrm{S}_{2.5}$ which was on par with $\mathrm{P}_{250}+\mathrm{S}_{2.5}$. But, the highest fruit setting rate (69.37\%) was obtained with $\mathrm{P}_{250}+\mathrm{S}_{2.5}$ resulting in higher number of fruits per cluster (4.94), fruits per plant (41.17), fruit weight $(77.60 \mathrm{~g})$, fruit diameter $(5.17 \mathrm{~cm})$. All these yield parameters were manifested into marketable tomato fruit yield recording maximum of $42.30 \mathrm{tha}^{-1}$ with $\mathrm{P}_{250}+\mathrm{S}_{2.5}$. The study established that application of $250 \mathrm{~kg} \mathrm{ha}^{-1} \mathrm{P}+2.5 \% \mathrm{~S}$ found to be statistically optimum for tomato in terms of its yield (42.30 ton ha $\left.{ }^{-1}\right)$.
\end{abstract}

Key words : Phosphorus, Sulphur, Calcareous soil, Tomato, Yield

How to cite this article : Kalpana, P.R., Suma, R. and Nagaraja, M.S. (2015). Influence of phosphorus and sulphur on growth, yield and yield attributes of tomato in calcareous soil. Asian J. Soil Sci., 10(1) : 119-124. 